\title{
Sediment Contamination Due to Toxic Heavy Metals in Mithi River of Mumbai
}

\author{
Pravin U. Singare*, Ravindra M. Mishra, Manisha P. Trivedi \\ Department of Chemistry, Bhavan's College, Munshi Nagar, Andheri (West), Mumbai, 400058, India
}

\begin{abstract}
The present study deals with quantification of accumulated toxic heavy metals in sediments of Mithi River of Mumbai. The study was performed at three different sampling locations along the flow of Mithi River for two years from 2009-12. The different heavy metals studied were $\mathrm{Al}, \mathrm{As}, \mathrm{Cd}, \mathrm{Cr}, \mathrm{Hg}, \mathrm{Ni}, \mathrm{Pb}, \mathrm{Sr}$ and $\mathrm{Mn}$. The results of our study indicate that the concentration level of these toxic heavy metals for the two assessment years increases by the factor of $1.2-5.8 \mu \mathrm{g} / \mathrm{g}$. The result is a clear indication of day by day increasing pollution level of the Mithi River, which is creating negative environmental impact on biological life of the river. The results emphasises the need of regular scientific monitoring of different pollutants adversely affecting the environment and to reframe the pollution control strategies already in existence.
\end{abstract}

Keywords Sediments, Toxic Heavy Metals, Quantification Study, Environmental Impact, Biological Life, Mithi River, Mumbai, India

\section{Introduction}

Among the inorganic contaminants of the river water, heavy metals are getting importance for their non-degradable nature and often accumulate through tropic level causing adeleterious biological effect. These toxic heavy metals are creating more serious environmental problem owing to their long biological half lives. It is also difficult to remove them completely from the environment once they enter into it. Rivers are a dominant pathway for transport of these heavy metals[1,2] which have become significant pollutants of many riverine systems. Anthropogenic activities like mining, ultimate disposal of treated/untreated waste effluents containing toxic metals as well as metal chelates[3] from different industries and also the indiscriminate use of heavy metal containing fertilizers and pesticides in agriculture resulted in deterioration of water quality rendering serious environmental problems posing threat on human beings[4] and sustaining aquatic biodiversity[5,6]. Though some of the metals like $\mathrm{Cu}, \mathrm{Fe}, \mathrm{Mn}, \mathrm{Ni}$ and $\mathrm{Zn}$ are essential as micro nutrients for life processes in plants and microorganisms, while many other metals like $\mathrm{Cd}, \mathrm{Cr}$ and $\mathrm{Pb}$ have unknown physiological activity, but they are proved detrimental beyond a certain limit[7], which is very much narrow for some elements like $\mathrm{Cd}(0.01 \mathrm{mg} / \mathrm{L}), \mathrm{Pb}(0.10 \mathrm{mg} / \mathrm{L})$ and $\mathrm{Cu}$ $(0.050 \mathrm{mg} / \mathrm{L})$. The deadlier diseases like edema of eyelids, tumor, congestion of nasal mucous membranes and pharynx,

* Corresponding author:

pravinsingare@gmail.com (Pravin U. Singare)

Published online at http://journal.sapub.org/aac

Copyright (C) 2012 Scientific \& Academic Publishing. All Rights Reserved stuffiness of the head and gastrointestinal, muscular, reproductive, neurological and genetic malfunctions caused by some of these heavy metals have been documented[8,9].

The behavior of metals in natural waters is a function of the substrate sediment composition, the suspended sediment composition, and the water chemistry. During their transport, the heavy metals undergo numerous changes in their speciation due to dissolution, precipitation, sorption and complexation phenomena[10, 11] which affect their behaviour and bioavailability[12, 13]. The overall behavior of heavy metals in an aquatic environment is strongly influenced by the associations of metals with various geochemical phases in sediments[14]. Due to their particle reactivity, metals tend to accumulate in sediments, and, as a result, may persist in the environment long after their primary source has been removed. These toxic metals are not necessarily fixed by the sediments permanently, but may be recycled via biological and chemical agents both within the sedimentary compartment as well as in the water column. Behaviour of these metals in the coastal marine sediments is largely related to their capacity for complexation with organic matter in truly dissolved, colloidal, macro particulate phases. These metals entering the ecosystem may lead to geoaccumulation, bioaccumulation, biomagnification and may have possibilities for environmental transformation into more toxic form. These toxic heavy metals entering in aquatic environment are adsorbed onto particulate matter, although they can form free metal ions and soluble complexes that are available for uptake by biological organisms[15] or get deposited in estuarine sediments[16]. Once deposited, binding by sulphides and/or iron hydroxides immobilizes trace metals until a change in redox or $\mathrm{pH}$ 
occurs[17, 18].In hydrosphere, toxic metal concentrations are typically orders of magnitude greater in the sediments as compared to those in overlying waters. Thus, superficial sediments, particularly the fine fraction, accumulate toxic heavy metals and provide a means for evaluating the long term accumulation of these metal contaminants[17, 19]. The capacity of sediments to concentrate trace levels of most of the metals also make them useful indicators for monitoring purposes and for detecting sources of pollution in the aquatic system. These heavy metals are sensitive indicators for monitoring changes in the water environment. Also the experimental data obtained based on analysis of sediment cores helps to provide a historical record of the heavy metal burdens. The monitoring these toxic heavy metals are important for safety assessment of the environment and human health in particular.

The problem of environmental pollution due to heavy metals has begun to cause concern now in most of the major metropolitan cities in Maharashtra state and Mumbai is not an exception to it. The day by day increasing tremendous pollution of water bodies[20-30] has prompted us to carry the systematic and detail study of pollution due to toxic heavy metals in sediments at different sampling stations along the flow of Mithi River which is considered as one of the heavily polluted river of Mumbai.

\section{Materials and Methods}

\subsection{Area of Study}

The water sampling was done from three different sampling stations along the flow of Mithi River namely Airport (L1), CST Kalina (L2) and BKC Taximen's Colony (L3). Airport site near Jari Mari area is thickly populated and has many small scale industries including scrap dealers. Previous short term study conducted by Maharashtra Pollution Control Board shows the presence of cyanide, consistent high COD, oil and grease found at this station indicating some chemical activity in that area[21]. Unauthorized encroachments by illegal industrial units, scrap dealers and oil mixing business at CST road near Kalina, have further resulted in discharge of solid waste, organic waste, industrial waste, heavy metals, oils and tar in the river. This sampling point is surrounded by many small scale industries including recyclers, barrel cleaners, workshops and other units. This area has thick density of population. Illegal activities like washing of oily drums have resulted in discharge of unauthorized hazardous waste which is carried out along the bank of this river. Development of Bandra-Kurla Complex has resulted in diversion and unnatural turn along the Mithi River at few places thereby affecting natural flow of the river and seriously affected the drainage. This part of the river is a dumping ground for garbage and it is reflected in higher values of suspended solids. The organic waste, sludge and garbage dumping has reduced the carrying capacity of the Mithi River. The solid wastes which is discharged in to the Mithi river from the surrounding illegal industries and the slums has resulted in sever water logging during 26/7 deluge in Mumbai. The map showing flow of Mithi River is shown in Figure 1.

\subsection{Climatic Conditions}

The area is located along western Arabian cost of India from 18 deg. 53' north to 19 deg. 16' north latitude and from 72 deg. east to 72 deg. 59 ' longitude. The area experiences tropical savanna climate. It receives heavy south west monsoon rainfall, measuring $2166 \mathrm{~mm}$ on an average every year. The temperature ranges from $16 \mathrm{deg}$. centigrade to 39 deg. centigrade with marginal changes between summer and winter months. Whereas relative humidity ranges between 54.5 to $85.5 \%$.

\subsection{Requirements}

The chemicals and reagent were used for analysis were of Analytical Reagent (AR) grade. The procedure for calculating the different parameters were conducted in the laboratory. The laboratory apparatus were soaked in nitric acid before the analysis. After acid soaked, it is rinsed thoroughly with tap water and de-ionised distilled water to ensure complete removal of any traces of cleaning reagents. Finally, it is dried and stored in a clean place. The pipettes and burette were rinsed with solution before final use.

\subsection{Sediment Sampling, Preparation and Analyses}

The sediment samples were collected randomly four times in a month in morning, afternoon and evening session from three different sampling stations along the flow of Mithi River (Figure 1). The samples were collected and subsequently analysed for a span of two years starting from October 2009 to September 2011. The sampling was done in three shifts i.e. morning shift between 07:00 a.m. to 09:00 a.m., afternoon shift between 02:00 p.m. to 04:00 p.m. and evening shift between 07:00 p.m. to 09:00 p.m. Sediment samples were collected by hand-pushing plastic core tubes $(7$ $\mathrm{cm}$ diameter) as far as possible into the sediment. The sediment cores retrieved in the field were sliced on arrival at the lab at $1-\mathrm{cm}$ depth intervals for the first $15 \mathrm{~cm}, 2-\mathrm{cm}$ depth intervals from $15-25 \mathrm{~cm}$, and then every $5 \mathrm{~cm}$ for the deeper sections of the cores. The sediments were kept cool in icebox during the transportation to the laboratory[31, 32]. They were then ground manually to a fine powder in an alumina mortar; passed through a 2-mm mesh screen and stored / preserved in polyethylene bags for further analysis. Well-mixed samples of $2 \mathrm{~g}$ each was taken in $250 \mathrm{~mL}$ glass beakers and digested with $8 \mathrm{~mL}$ of aqua regia on a sand bath for $2 \mathrm{hr}$. After evaporation to near dryness, the samples were dissolved with $10 \mathrm{~mL}$ of $2 \%$ nitric acid and filtered through Whatman's No.1 filter paper. The samples were subjected to nitric acid digestion using the microwave-assisted technique, setting pressure at $30 \mathrm{bar}$ and power at $700 \mathrm{~W}[33,34]$. About $400 \mathrm{~mL}$ of the sample was transformed into clean glass separating funnel in which $10 \mathrm{~mL}$ of $2 \%$ ammonium 
pyrrolidine dithiocarbamate, $4 \mathrm{~mL}$ of $0.5 \mathrm{M} \mathrm{HCl}$ and $10 \mathrm{~mL}$ of methyl isobutyl ketone (MIBK) are added[35]. The solution in separating funnel was shaken vigorously for 2 min and was left undisturbed for the phases to separate. The MIBK extract containing the desired metals was then diluted to give final volumes depending on the suspected level of the metals[36]. The sample solution was then aspirated into air acetylene flame in an atomic absorption spectrophotometer.

\subsection{Heavy Metal Analysis By AAS Technique}

The analysis for the majority of the trace metals like aluminum $(\mathrm{Al})$, cadmium $(\mathrm{Cd})$, chromium $(\mathrm{Cr})$, nickel $(\mathrm{Ni})$, lead $(\mathrm{Pb})$, strontium $(\mathrm{Sr})$ and manganese $(\mathrm{Mn})$ was done by Perkin Elmer ASS-280 Flame Atomic Absorption Spectrophotometer. Arsenic (As) was determined by hydride generation coupled with an atomic fluorescence detector, while mercury $(\mathrm{Hg})$ was analysed with a cold-vapour atomic adsorption spectrophotometer. An atomizer with an air/acetylene burner was used for determining all the elements investigated. All instrumental settings were those recommended in the manufacturer's manual book. To analyse the solutions extracted, an aliquot $100 \mu \mathrm{L}$ of the solution was introduced to nebulizer of flame AAS. The detection limits of $\mathrm{Al}, \mathrm{As}, \mathrm{Cd}, \mathrm{Cr}, \mathrm{Hg}, \mathrm{Ni}, \mathrm{Pb}, \mathrm{Sr}$ and $\mathrm{Mn} 15$, $20,2,20,5,25,45,10$ and $5 \mu \mathrm{g} / \mathrm{g}$ respectively. The calibration curves were prepared separately for all the metals by running different concentrations of standard solutions. A reagent blank was taken through the method, analyzed and subtracted from the samples to correct for reagent impurities and other sources of errors from the environment. Average values of three replicates were taken for each determination.

\subsection{Quality Control/Assurance}

Sediment samples were collected with plastic-made implements to avoid contamination. Samples were kept in polythene bags that were free from heavy metals and organics and well covered while transporting from field to the laboratory to avoid contamination from the environment. Reagent blanks were used in all analyses to check reagent impurities and other environmental contaminations during analyses. Analytical grade reagents were used for all analyses. All glassware used were soaked in appropriate dilute acids overnight and washed with teepol and rinsed with deionised water before use. Tools and work surfaces were carefully cleaned for each sample during grinding to avoid cross contamination. Replicate samples were analysed to check precision of the analytical method and instrument. To validate the analytical procedures used, the spike recovery test was conducted on some sediment samples for $\mathrm{Al}, \mathrm{As}, \mathrm{Cd}, \mathrm{Cr}, \mathrm{Ni}, \mathrm{Pb}, \mathrm{Sr}, \mathrm{Mn}$ and $\mathrm{Hg}$.

\section{Results and Discussion}

Toxic heavy metals are released into the environment from metal smelting and refining industries, scrap metal, plastic and rubber industries, various consumer products and from burning of waste containing these elements. On release to the air, the elements travel for large distances and are deposited onto the soil, vegetation and water depending on their density. Discharge of treated/partially treated or untreated domestic and agricultural wastes also leads to the pollution of water bodies due to the heavy metals[37]. These metals entering in aquatic environment are adsorbed onto particulate matter, although they can form free metal ions and soluble complexes that are available for uptake by biological organisms. The metals associated with particulate material are also available for biological uptake, and are deposited in estuarine sediments[38]. Once deposited, binding by sulfides and/or iron hydroxides immobilises trace metals until a change in redox or $\mathrm{pH}$ occurs. Thus, surfical sediments, particularly the fine fraction, accumulate trace metals and provide a means for evaluating the long term accumulation of heavy metal contaminants[39]. These heavy metals which are accumulated in sediments are not degraded and persist in the environment for many years poisoning humans through inhalation, ingestion and skin absorption. Acute exposure leads to nausea, anorexia, vomiting, gastrointestinal abnormalities and dermatitis.

The experimental data on concentration $(\mu \mathrm{g} / \mathrm{g})$ of toxic heavy metals like $\mathrm{Al}, \mathrm{As}, \mathrm{Cd}, \mathrm{Cr}, \mathrm{Hg}, \mathrm{Ni}, \mathrm{Pb}, \mathrm{Sr}$ and $\mathrm{Mn}$ in the sediment samples collected along sampling stations L1, L2 and L3 of Mithi River is presented in Table 1. The trend in average concentration of these metals at different sampling stations for the assessment years 2009-10 and 2010-11 is graphically represented in Figures 2-4.

From the results it was observed that aluminum $(A l)$ concentration at different sampling stations lies in the range of $22-243,52-729$, and $32-851 \mu \mathrm{g} / \mathrm{g}$ at the respective sampling stations. The biyearly average $\mathrm{Al}$ concentration was found to be 77,212 and $250 \mu \mathrm{g} / \mathrm{g}$ respectively at different sampling stations (Table 1). It was also observed that the average $\mathrm{Al}$ concentration for assessment year 2010-11 was higher than that obtained for the assessment year 2009-10 by a factor of 3.03 at L1 to 3.43 at L2 sampling stations (Figures 2-5). It is important here to note that aluminum toxicity is an important growth-limiting factor for plants in many acid soils, particularly in $\mathrm{pH}$ of 5.0 or below[40]. Aluminum toxicity in plants is often clearly identifiable through morphological and physiological symptoms. Differential tolerances to $\mathrm{Al}$ toxicity almost certainly involves differences in the structure and function of roots. Aluminum interferes with cell division in roots, decreases root respiration and uptake and use of water and nutrients, particularly calcium and phosphorous and metabolic pathway[41-43].

Levels of arsenic $(A s)$ are higher in the aquatic environment than in most areas as it is fairly water-soluble and may be washed out of arsenic bearing rocks. Recently, the anthropogenic activities such as treatment of agricultural land with arsenical pesticides, treating of wood using chromated copper arsenate, burning of coal in thermal plants power stations and the operations of gold-mining have increased the environmental pervasiveness of $A s$ and its rate 
of discharge into freshwater habitat. Arsenic can also interfere with the fish immune system by suppressing antibody production[44] as well as by lowering macrophage activity and maturation[45]. Several studies are reporting $A s$ induced liver fibrosis, hepatocellular damage, inflammation, focal necrosis in addition to hepatocellular carcinoma[46]. In the present investigation it was observed that As concentration at L1, L2 and L3 sampling stations lies in the range of 26-450, 73-1530 and 56-1755 $\mu \mathrm{g} / \mathrm{g}$ respectively. The biyearly average $A s$ concentration was found to be 162 , 509 and $585 \mu \mathrm{g} / \mathrm{g}$ respectively at different sampling stations (Table 1). It was also observed that the average As concentration for assessment year 2010-11 was higher than that obtained for the assessment year 2009-10 by a factor of 3.98 at L1 to 4.25 at L2 sampling stations (Figures 2-5).

Although emissions of cadmium $(C d)$ in the environment have markedly declined in most industrialized countries, $C d$ remains a source of concern for industrial workers and for populations living in polluted areas, especially in less developed countries[47]. $C d$ dispersed in the environment can persist in soils and sediments for decades[48]. When taken up by plants, $C d$ concentrates along the food chain and ultimately accumulates in the body of people eating contaminated foods[48]. By far, the most salient toxicological property of $C d$ is its exceptionally long half-life in the human body. Once absorbed, $C d$ irreversibly accumulates in the human body, in particularly in kidneys and other vital organs such the lungs or the liver

[49]. In addition to its extraordinary cumulative properties, $C d$ is also a highly toxic metal that can disrupt a number of

biological systems, usually at doses that are much lower than most toxic metals[50]. In the present investigation it

was observed that $C d$ concentration at L1, L2 and L3 sampling stations lies in the range of 12-398, 16-440 and $5-890 \mu \mathrm{g} / \mathrm{g}$ respectively. The biyearly average $C d$ concentration was found to be 157,140 and $308 \mu \mathrm{g} / \mathrm{g}$ respectively at different sampling stations (Table 1). It was also observed that the average $C d$ concentration for assessment year 2010-11 was higher than that obtained for the assessment year 2009-10 by a factor of 5.04 at L1 to 5.78 at L3 sampling stations (Figures 2-5).

Chromium $(\mathrm{Cr})$ is one of the most common skin sensitizers and often causes skin sensitizing effect in the general public. A possible source of chromium exposure is waste dumps for chromate-producing plants causing local air or water pollution. Penetration of the skin will cause painless erosive ulceration ("chrome holes") with delayed healing. These commonly occur on the fingers, knuckles, and forearms. The characteristic chrome sore begins as a papule, forming an ulcer with raised hard edges. Ulcers can penetrate deep into soft tissue or become the sites of secondary infection, but are not known to lead to malignancy[51, 52]. Besides the lungs and intestinal tract, the liver and kidney are often target organs for chromate toxicity[53]. In natural waters, exposure to $\mathrm{Cr}$ has demonstrated cumulative deleterious effects on fishes as a function of time[54, 55]. In the present investigation it was observed that $\mathrm{Cr}$ concentration at L1, L2 and L3 sampling stations lies in the range of 92-932, 25-1656 and 63-1822 $\mu \mathrm{g} / \mathrm{g}$ respectively. The biyearly average $\mathrm{Cr}$ concentration was found to be 348 , 491 and $593 \mu \mathrm{g} / \mathrm{g}$ respectively at different sampling stations (Table 1). It was also observed that the average $\mathrm{Cr}$ concentration for assessment year 2010-11 was higher than that obtained for the assessment year 2009-10 by a factor of 2.10 at $\mathrm{L} 3$ to 2.50 at $\mathrm{L} 1$ and L2 sampling stations (Figures 2-5).

Mercury $(\mathrm{Hg})$ poisoning has become a problem of current interest as a result of environmental pollution on a global scale. Mercury is a strong phytotoxic as well as genotoxic metal. High concentration of mercury, which could pose an ecological hazard, leading to contamination of plants[56, 57], aquatic resources and bioaccumulation in the food chain[58]. Although elemental mercury is relatively innocuous and non-toxic, it can be converted to organomercurials, which are particularly toxic and are retained in the cells of plants and living organisms. Reports by Tanaka[59] and Goldstone et al.[60] have dwelt on the natural alkylation of total mercury in waste water and water bodies. Recent studies have also reported that the inorganic mercury is transformed into methylmercury through microbial activity, which is the most toxic and most bioavailable form of mercury for living organisms[61]. Bodaly et al.[62] have reported that treated sewage water discharged into rivers and similar water bodies could result in an appreciable increase in the buildup of alkyl mercury. In the present investigation it was observed that $\mathrm{Hg}$ concentration at L1, L2 and L3 sampling stations lies in the range of 32-389, 20-238 and 13-97 $\mu \mathrm{g} / \mathrm{g}$ respectively. The biyearly average $\mathrm{Hg}$ concentration was found to be 189,70 and $56 \mu \mathrm{g} / \mathrm{g}$ respectively at different sampling stations (Table 1). It was also observed that the average $\mathrm{Hg}$ concentration for assessment year 2010-11 was higher than that obtained for the assessment year 2009-10 by a factor of 1.20 at $\mathrm{L} 3$ to 2.71 at $\mathrm{L} 2$ sampling stations (Figures 2-5).

Nickel $(\mathrm{Ni})$ and nickel compounds have many industrial and commercial uses, and the progress of industrialization has led to increased emission of pollutants into ecosystems. Nickel is easily accumulated in the biota, particularly in the phytoplankton or other aquatic plants, which are sensitive bioindicators of water pollution. It can be deposited in the sediment by such processes as precipitation, complexation and adsorption on clay particles and via uptake by biota[63, 64]. Levels of precipitation of $N i$ of $0.9 \mathrm{mg} / \mathrm{m}^{2} /$ year over long periods were found to be dangerous for biological systems of fresh water catchments[65]. In rivers, nickel is transported mainly as a precipitated coating on particles and in association with organic matter. Recent studies have suggested an increase in cancer in nickel refinery areas where exposure to water-soluble nickel salts occurs[66]. Nickel has been shown to be immunotoxic, altering the activity of all specific types involved in the immunological response, resulting in contact dermatitis or asthma. Human exposure to highly nickel-polluted environments has the potential to produce a variety of pathological effects. Among them are skin allergies, lung fibrosis, cancer of the 
respiratory tract and iatrogenic nickel poisoning[67]. While no reproductive effects have been associated with nickel exposure to humans, several studies on laboratory animals have demonstrated fetotoxicity[68]. In the present investigation it was observed that $\mathrm{Ni}$ concentration at L1, L2 and L3 sampling stations lies in the range of 65-2157, 36-384 and $66-2427 \mu \mathrm{g} / \mathrm{g}$ respectively. The biyearly average $N i$ concentration was found to be 1087, 205 and $1289 \mu \mathrm{g} / \mathrm{g}$ respectively at different sampling stations (Table 1). It was also observed that the average $N i$ concentration for assessment year 2010-11 was higher than that obtained for the assessment year 2009-10 by a factor of 1.50 at L3 to 1.70 at L1 and L2 sampling stations (Figures 2-5).

Lead $(P b)$ inhibits plant growth, reduces photosynthesis, and reduces mitosis and water absorption. Lead concentrations in aquatic (and terrestrial) vertebrates tend to increase with increasing age of the organism, and to localize in hard tissues such as bone and teeth. Tetramethyl lead reportedly was produced from biological and chemical methylation of several inorganic and organic $\mathrm{Pb}$ compounds in the aquatic environment, and has been detected at low concentrations in marine mussels, lobsters, and bony fishes.

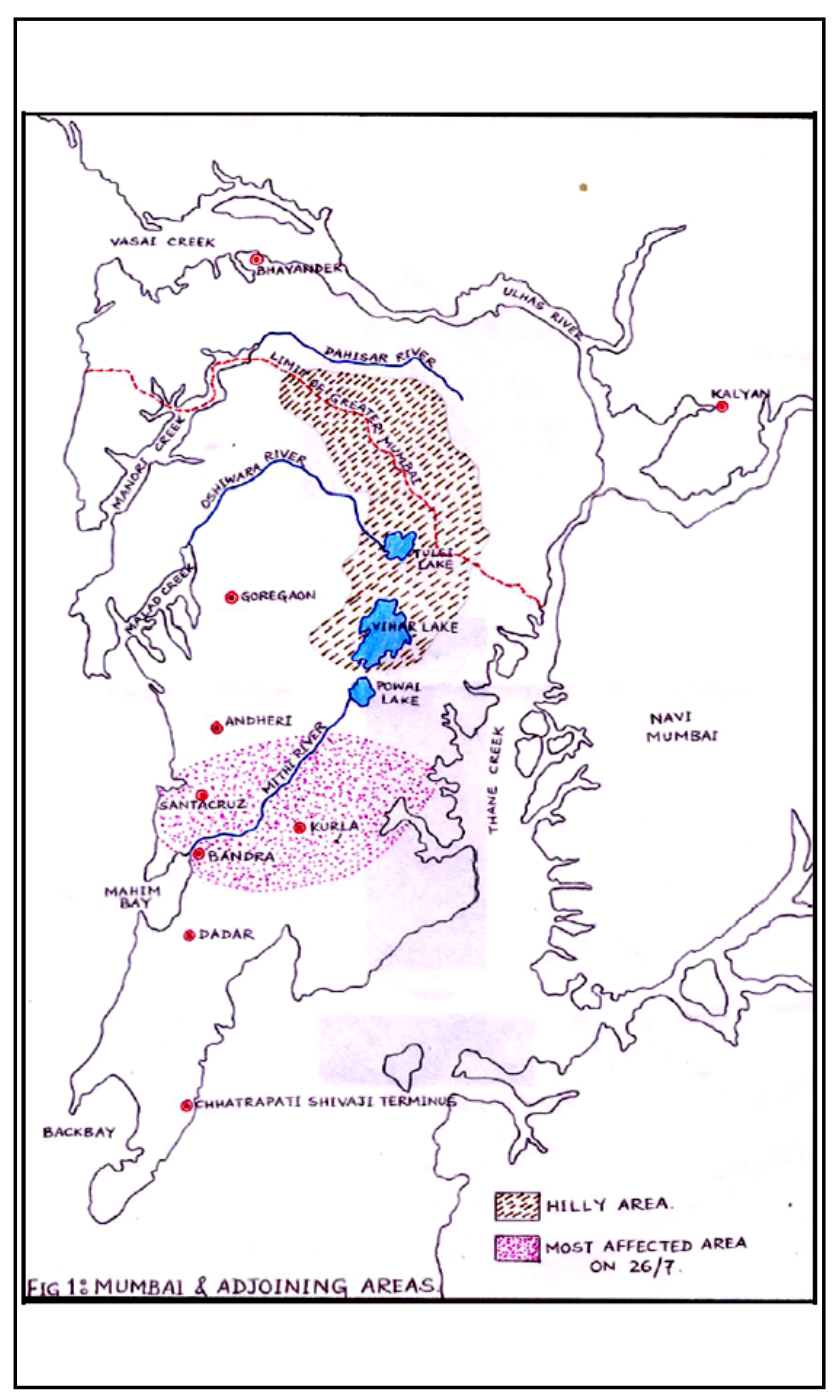

Figure 1. Map showing flow of Mithi River in Mumbai

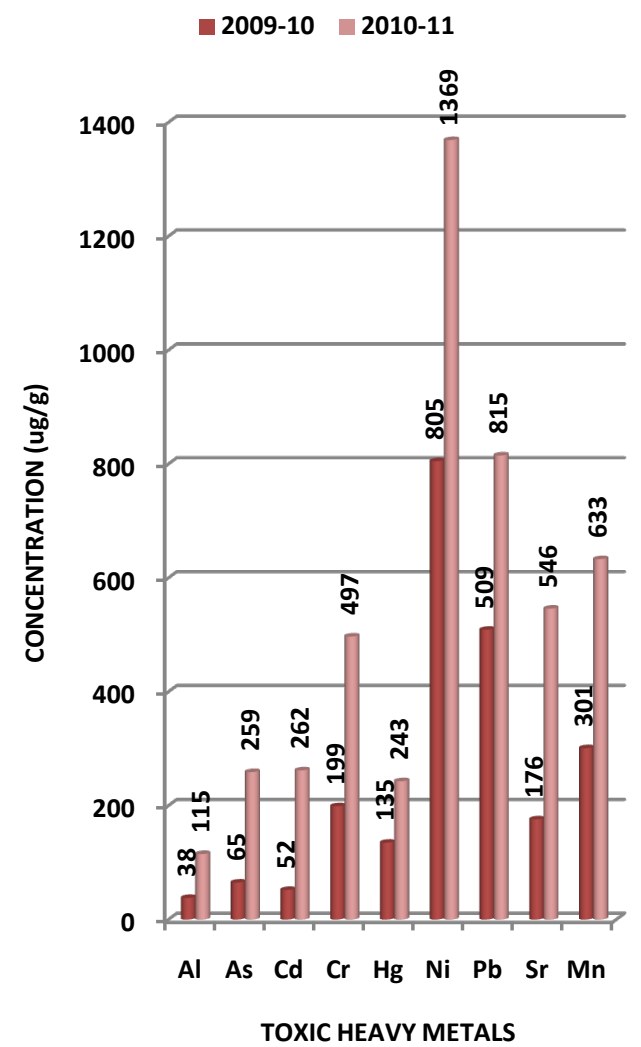

Figure 2. Variation in average concentration values of different toxic heavy metals in sediment samples collected at L-1 sampling station of Mithi River during the assessment year 2009-10 and 2010-11

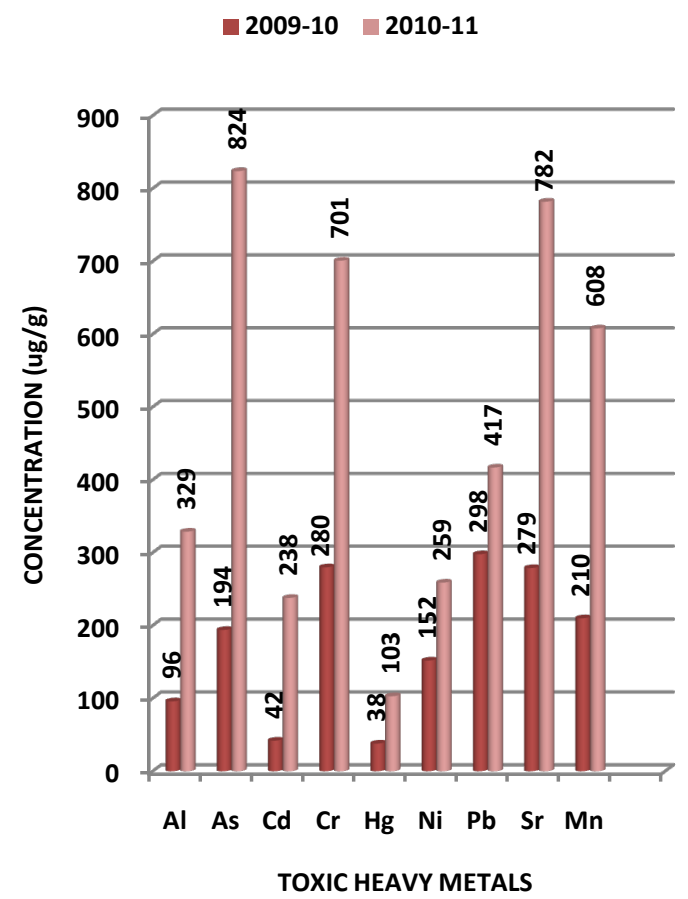

Figure 3. Variation in average concentration values of different toxic heavy metals in sediment samples collected at L-2 sampling station of Mithi River during the assessment year 2009-10 and 2010-11 


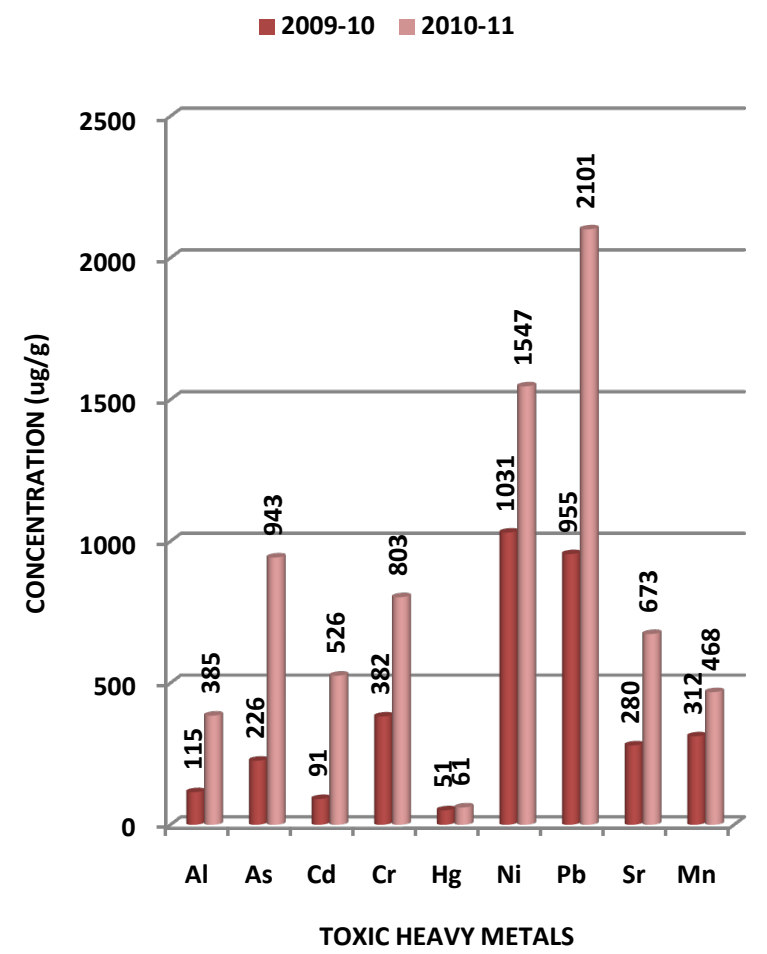

Figure 4. Variation in average concentration values of different toxic heavy metals in sediment samples collected at L-3 sampling station of Mithi River during the assessment year 2009-10 and 2010-11

Table 1. Heavy Metal Content in Sediment Samples Collected at different Sampling Stations along Mithi River of Mumbai (values in $\mu \mathrm{g} / \mathrm{g}$ dry weight)

\begin{tabular}{|c|c|c|c|c|c|c|c|c|c|c|c|c|}
\hline $\begin{array}{l}\text { Heavy } \\
\text { Metals }\end{array}$ & \multicolumn{3}{|c|}{ Al } & \multicolumn{3}{|c|}{ As } & \multicolumn{3}{|c|}{ Cd } & \multicolumn{3}{|c|}{$\mathrm{Cr}$} \\
\hline $\begin{array}{l}\text { Sampling } \\
\text { Stations }\end{array}$ & \multirow[t]{2}{*}{ L1 } & \multirow[t]{2}{*}{ L2 } & \multirow[t]{2}{*}{ L3 } & \multirow[t]{2}{*}{ L1 } & \multirow[t]{2}{*}{ L2 } & \multirow[t]{2}{*}{ L3 } & \multirow[t]{2}{*}{ L1 } & \multirow[t]{2}{*}{ L2 } & \multirow[t]{2}{*}{ L3 } & \multirow[t]{2}{*}{ L1 } & \multirow[t]{2}{*}{ L2 } & \multirow[t]{2}{*}{ L3 } \\
\hline Month-Year & & & & & & & & & & & & \\
\hline October-09 & 26 & 65 & 78 & 76 & 229 & 267 & 63 & 42 & 125.2 & 114 & 341 & 446 \\
\hline November & 23 & 58 & 69 & 81 & 242 & 283 & 71 & 47 & 142.4 & 123 & 370 & 484 \\
\hline December & 33 & 83 & 100 & 75 & 225 & 263 & 59 & 40 & 118.8 & 110 & 331 & 434 \\
\hline January-10 & 30 & 75 & 90 & 69 & 206 & 241 & 54 & 36 & 107.2 & 92 & 303 & 419 \\
\hline February & 41 & 103 & 123 & 67 & 200 & 233 & 57 & 38 & 114 & 119 & 358 & 468 \\
\hline March & 49 & 122 & 146 & 70 & 209 & 243 & 60 & 40 & 120.4 & 133 & 400 & 523 \\
\hline April & 53 & 133 & 159 & 77 & 231 & 270 & 76 & 51 & 151.6 & 161 & 482 & 632 \\
\hline May & 81 & 203 & 243 & 113 & 338 & 394 & 80 & 53 & 159.2 & 221 & 662 & 867 \\
\hline June & 45 & 113 & 136 & 55 & 164 & 192 & 55 & 77 & 26 & 302 & 25 & 63 \\
\hline July & 34 & 85 & 102 & 41 & 123 & 144 & 27 & 37 & 12 & 339 & 28 & 73 \\
\hline August & 24 & 60 & 72 & 28 & 85 & 99 & 12 & 16 & 5 & 373 & 31 & 88 \\
\hline September & 22 & 54 & 65 & 26 & 79 & 92 & 17 & 24 & 8 & 300 & 33 & 90 \\
\hline October & 78 & 234 & 273 & 305 & 1068 & 1190 & 313 & 261 & 783 & 284 & 852 & 937 \\
\hline November & 69 & 207 & 242 & 323 & 1131 & 1260 & 356 & 297 & 890 & 308 & 924 & 1016 \\
\hline December & 100 & 300 & 350 & 300 & 1050 & 1170 & 297 & 248 & 743 & 276 & 828 & 911 \\
\hline January-11 & 90 & 233 & 320 & 275 & 921 & 928 & 268 & 103 & 615 & 229 & 758 & 880 \\
\hline February & 123 & 369 & 431 & 266 & 904 & 1037 & 285 & 219 & 627 & 298 & 894 & 983 \\
\hline March & 146 & 438 & 511 & 278 & 945 & 1084 & 301 & 232 & 662 & 333 & 999 & 1099 \\
\hline April & 159 & 477 & 557 & 308 & 1047 & 1201 & 379 & 292 & 834 & 402 & 1206 & 1327 \\
\hline May & 243 & 729 & 851 & 450 & 1530 & 1755 & 398 & 306 & 876 & 552 & 1656 & 1822 \\
\hline June & 136 & 408 & 476 & 219 & 745 & 1056 & 275 & 440 & 138 & 756 & 63 & 132 \\
\hline July & 102 & 306 & 357 & 164 & 357 & 498 & 133 & 213 & 67 & 848 & 71 & 153 \\
\hline August & 72 & 52 & 32 & 113 & 73 & 56 & 58 & 110 & 32 & 932 & 78 & 185 \\
\hline September & 65 & 190 & 228 & 105 & 115 & 77 & 86 & 138 & 44 & 750 & 83 & 190 \\
\hline AVERAGE & 77 & 212 & 250 & 162 & 509 & 585 & 157 & 140 & 308 & 348 & 491 & 593 \\
\hline Range & $22-243$ & $52-729$ & $32-851$ & $26-450$ & $73-1530$ & $56-1755$ & $12-398$ & $16-440$ & $5-890$ & $92-932$ & $25-1656$ & $63-1822$ \\
\hline Median & 132 & 391 & 441 & 238 & 802 & 906 & 205 & 228 & 448 & 512 & 841 & 942 \\
\hline
\end{tabular}


Table 1. Heavy Metal Content in Sediment Samples Collected at different Sampling Stations along Mithi River of Mumbai (values in $\mu \mathrm{g} / \mathrm{g}$ dry weight) (continue)

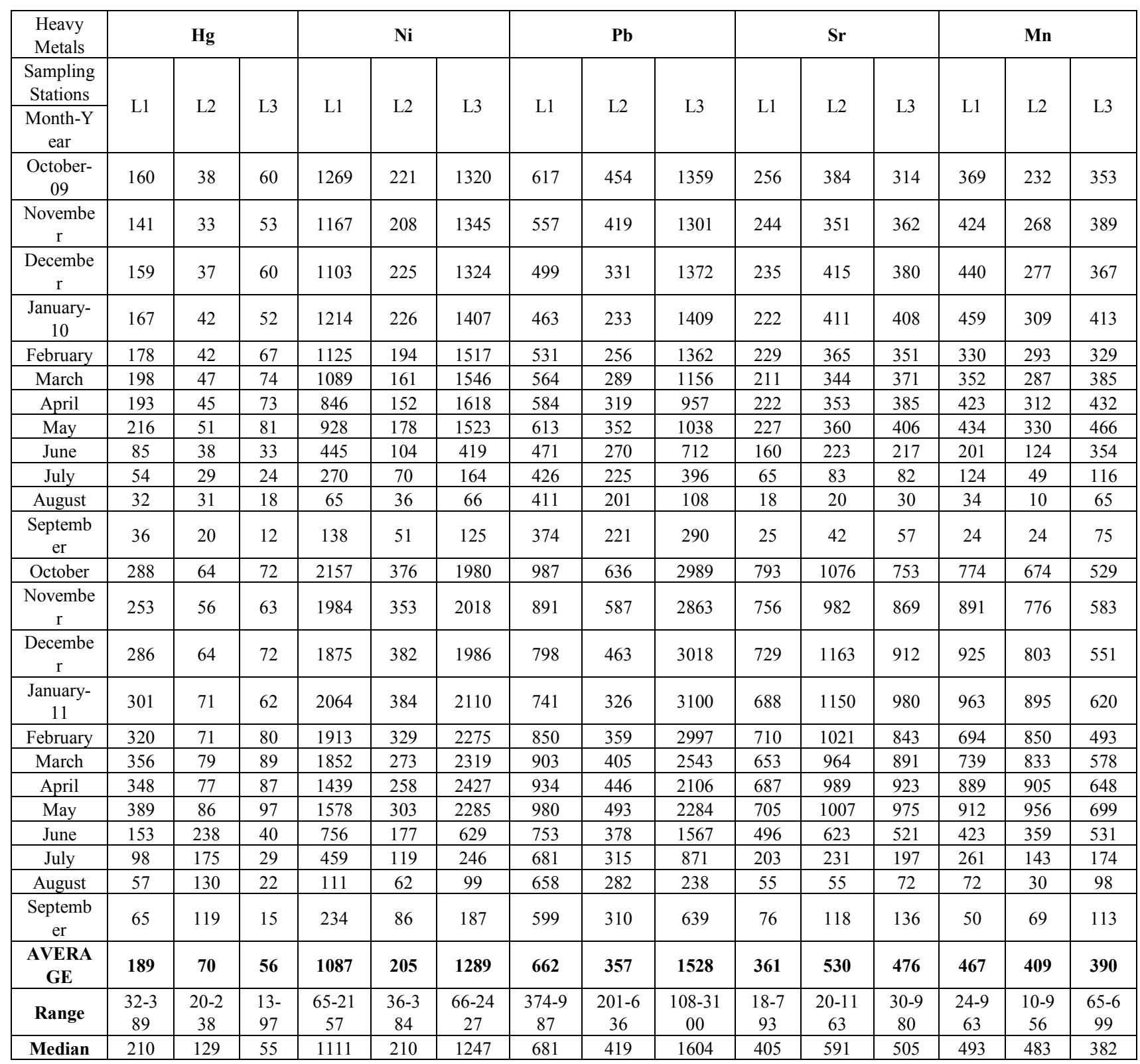

High $P b$ concentration caused adverse physiological and reproductive effects in some species of birds and mammals[69]. Lead adversely affects survival, growth, reproduction, development, and metabolism of most species under controlled conditions, but its effects are substantially modified by numerous physical, chemical, and biological variables. Inorganic $P b$ in the environment can be biologically methylated to produce alkyl lead compounds.

Some microorganisms in lake sediments transform certain inorganic and organic $\mathrm{Pb}$ compounds into the more toxic tetramethyl lead, but the pathways are not well understood.

In general, organolead compounds are more toxic than inorganic $\mathrm{Pb}$ compounds, food chain biomagnifications of $P b$ is negligible, and the younger, immature organisms are most susceptible. Axonal degenerative changes, especially in neuronal cell bodies, were recorded in $P b$-poisoned freshwater snails (Viviparous ater), leading to altered protein synthesis[70]. Tetraethyl lead was about 10 times more effective than tetramethyl lead in reducing oxygen consumption by coastal marine bacteria, and was 1.5 to 4 times more toxic than tetramethyl lead to marine teleosts. Increasing waterborne concentrations of $P b$ over $10 \mu \mathrm{g} / \mathrm{L}$ are expected to provide increasingly severe long-term effects on fish and fisheries. Lead seems to be tightly bound by most soils, and substantial amounts must accumulate before it affects the growth of higher plants. In the present investigation it was observed that $P b$ concentration at L1, L2 and L3 sampling stations lies in the range of 374-987, 201-636 and 108-3100 $\mu \mathrm{g} / \mathrm{g}$ respectively. The biyearly average $P b$ concentration was found to be 662,357 and 1528 
$\mu \mathrm{g} / \mathrm{g}$ respectively at different sampling stations (Table 1 ). It was also observed that the average $P b$ concentration for assessment year 2010-11 was higher than that obtained for the assessment year 2009-10 by a factor of 1.40 at L2 to 2.20 at L3 sampling stations (Figures 2-5).

Strontium $(\mathrm{Sr})$ compounds that are water-insoluble can become water-soluble, as a result of chemical reactions. The water-soluble compounds are a greater threat to human health than the water-insoluble ones. Therefore, water-soluble forms of strontium have the opportunity to pollute aquatic environment. For children exceeded strontium uptake may be a health risk, because it can cause problems with bone growth. In the present investigation it was observed that $\mathrm{Sr}$ concentration at L1, L2 and L3 sampling stations lies in the range of 18-793, 20-1163 and $30-980 \mu \mathrm{g} / \mathrm{g}$ respectively. The biyearly average $\mathrm{Sr}$ concentration was found to be 361,530 and $476 \mu \mathrm{g} / \mathrm{g}$ respectively at different sampling stations (Table 1). It was also observed that the average $S r$ concentration for assessment year 2010-11 was higher than that obtained for the assessment year $2009-10$ by a factor of 2.40 at L3 to 3.10 at L1 sampling stations (Figures 2-5).

Manganese $(\mathrm{Mn})$ is one out of three toxic essential trace elements, which means that it is not only necessary for humans to survive, but it is also toxic when too high concentrations are present in a human body. Excess manganese interferes with the absorption of dietary iron. Long-term exposure to excess levels may result in iron-deficiency anaemia. Increased manganese intake impairs the activity of copper metallo-enzymes. The presence of manganese in drinking water supplies may be objectionable for a number of reasons unrelated to health. At concentrations exceeding $0.15 \mathrm{mg} / \mathrm{L}$, manganese stains plumbing fixtures and laundry and causes undesirable tastes in beverages[71]. Oxidation of manganese ions in solution results in precipitation of manganese oxides and incrustation problems. Even at concentrations of approximately $0.02 \mathrm{mg} / \mathrm{L}$, manganese may form coatings on water distribution pipes that may slough off as black precipitates[72]. The growth of certain nuisance organisms is also supported by manganese[71, 73]. The presence of "manganese" bacteria, which concentrate manganese, may give rise to taste, odour and turbidity problems in the distributed water. Highly toxic concentrations of manganese in soils can cause swelling of cell walls, withering of leafs and brown spots on leaves. In the present investigation it was observed that $M n$ concentration at L1, L2 and L3 sampling stations lies in the range of 24-963, 10-956 and 65-699 $\mu \mathrm{g} / \mathrm{g}$ respectively. The biyearly average $M n$ concentration was found to be 467, 409 and $390 \mu \mathrm{g} / \mathrm{g}$ respectively at different sampling stations (Table 1). It was also observed that the average $M n$ concentration for assessment year 2010-11 was higher than that obtained for the assessment year 2009-10 by a factor of 1.50 at L3 to 2.90 at L2 sampling stations (Figures 2-5).

\section{Conclusions}

Heavy metal pollution is an ever-increasing problem of our oceans, lakes and rivers. Incidence of heavy metal accumulation in fish, oysters, sediments and other components of aquatic ecosystems have been reported from all over the world. Environmental problems concerning coastal and aquatic bodies cannot be addressed in isolation. They are intricately interwoven with each other. The environments of land and sea are interdependent, linked by complex atmospheric, geological, physical, chemical and biological interactions. The human activities that affect and arise from this environment also depend on economic and social factors. The problem is beyond the limits of physical and institutional bodies and therefore, there is a need to set common objectives and implement compatible policies and programmes. Today, it is realised that solution to environmental problem can only be achieved through a comprehensive, systematic and sustained approach. During the past few years, attempts were made by various groups to develop strategies directed towards more integrated approach in coastal environments. The present data on heavy metal pollution in sediment samples collected along the Mithi River of Mumbai also points out to the need of regular monitoring of water resources and further improvement in the industrial wastewater treatment methods. What is more fundamentally lacking is a consistent, internationally recognised and data driven strategy to assess the quality of aquatic bodies and generation of international standards for evaluation of levels of contaminants.

\section{ACKNOWLEDGEMENTS}

The authors are thankful to SAP Productions for developing and maintaining the paper template.

\section{REFERENCES}

[1] Miller, C. V., Foster, G. D., and Majedi, B. F., 2003, Base flow and storm flow metal fluxes from two small agricultural catchments in the coastal plain of Chesapeake Bay Basin, United States. Appl. Geochem., 18 (4), 483-501.

[2] Harikumar, P. S., Nasir, U. P., and Mujeebu Rahman, M.P., 2009, Distribution of heavy metals in the core sediments of a tropical wetland system. Int. J. Environ. Sci. Tech., 6 (2), 225-232.

[3] Amman, A. A., Michalke, B., and Schramel, P., 2002, Speciation of heavy metals in environmental water by ion chromatography coupled to ICP-MS. Anal. Biochem., 372(3), $448-452$.

[4] Ross, S.M., 1994, Toxic metals in soil-plant systems, Wiley, Chichester, U.K.

[5] Das, R.K., Bhowmick, S., Ghosh, S.P., and Dutta, S., 1997, Coliform and fecal coliform bacterial load in a stretch of 
Hooghly, in K. K Vass and M. Sinha, (Eds.), Proceedings of the National seminar on changing perspectives of inland fisheries, Inland Fisheries Society of India, Barrackpore.

[6] Ghosh, S., and Vass, K. K., 1997, Role of sewage treatment plant in Environmental mitigation. K. K. Vass and M. Sinha (Eds.), Proceedings of the national seminar on changing perspectives of inland fisheries, Inland Fisheries Society of India, Barrackpore, 36 -40.

[7] Bruins, M.R., Kapil, S., and Oehme, F.W., 2000, Microbial resistance to metals in the environment, Ecotox. Environ. Safe. 45(3), 198-207.

[8] Johnson, F. M., 1998, The genetic effects of environmental lead., Mutat. Res., 410(2), 123-140.

[9] Tsuji, L. J. S., and Karagatzides, J. D., 2001, Chronic lead exposure, body condition and testis mass in wild Mallard Ducks, Bull. Environ. Contam. Tox., 67(4) , 489 -495 .

[10] Akcay, H., Oguz, A., and Karapire,C., 2003, Study of heavy metal pollution and speciation in Buyak Menderes and Gediz river sediments. Water Res., 37(4), 813-822.

[11] Abdel-Ghani, N. T., and Elchaghaby, G. A., 2007, Influence of operating conditions on the removal of $\mathrm{Cu}, \mathrm{Zn}, \mathrm{Cd}$ and $\mathrm{Pb}$ ions from waste water by adsorption. Int. J. Environ. Sci. Tech., c4 (4), 451 - 456 .

[12] Nicolau, R., Galera, C.A., and Lucas, Y., 2006, Transfer of nutrients and labile metals from the continent to the sea by a small Mediterranean river. Chemosphere, 63(3), 469-476.

[13] Nouri, J., Lorestani, B., Yousefi, N., Khorasani, N., Hasani, A. H., Seif, S., Cheraghi, M., 2011, Phyto remediation potential of native plants grown in the vicinity of Ahangaran lead-zinc mine (Hamedan, Iran). Environ. Earth Sci., 62(3), 639 -644.

[14] Morillo, J., Usero, J., Gracia, I., 2004, Heavy metal distribution in marine sediments from the southwest coast of Spain, Chemosphere, 55 (3), 431-442.

[15] Lee, B.G., Griscom, S.B., Lee, J.S., Choi, H.J., Koh, C.H., Luoma, S.N., and Fisher, N.S., 2000, Influence of dietary uptake and reactive sulfides on metal availability from aquatic sediments, Science, 287(5451): 282-84.

[16] Weston, D.P., and Maraya, K.A., 2002, Predicting bioavailability and bioaccumulation with in vitro digestive fluid extraction. Environ. Toxicol. Chem., 21(05):962-971.

[17] Adams, W.J., Kimerle, R.A., and Barnett, J.W. Jr., 1992, Sediment quality: and aquatic life assessment. Environ Sci. Technol., 26 (10):1864-75.

[18] Maher, W., Batley, G.E., Lawrence, I., 1999, Assessing the health of sediment ecosystems: use of chemical measurements. Freshwater Biol., 41(2): 361-72.

[19] Kennicutt, M.C., Wade, T.L., Presley, B.J., Requejo, A.G., Brooks, J.M., and Denoux, G.J., 1994, Sediment contaminants in Casci Bay, Maine: inventories, sources and potential for biological impacts. Environ Sci Technol., 28(1): $1-15$.

[20] Modak, D.M., Singh, K.P., Ahmed, S., and Ray, P.K., 1990, Trace metal ion in Ganga water system. Chemosphere, 21 $(1-2): 275-87$

[21] Rajaram, T., Das, A., 2008, Water pollution by industrial effluents in India: discharge scenarios and case for participatory ecosystem specific local regulation. Futures, 40(1):56-69.

[22] Lokhande, R.S., Singare, P.U., and Pimple, D.S., 2011, Toxicity Study of Heavy Metals Pollutants in Waste Water Effluent Samples Collected From Taloja Industrial Estate of Mumbai, India, Resources and Environment, 1(1): 13-19.

[23] Lokhande, R.S., Singare, P.U., and Pimple, D.S., 2011, Quantification Study of Toxic Heavy Metals Pollutants in Sediment Samples Collected from Kasardi River Flowing along the Taloja Industrial Area of Mumbai, India, The New York Science Journal, 4(9), 66-71.

[24] Singare, P.U., 2011, Distribution Behaviour of Trace and Toxic Metals in Soil and Sediment along the Thane Creek Near Mumbai, India, Interdisciplinary Environmental Review, 12(4), 298-312.

[25] Singare, P.U., Lokhande, R.S., and Bhanage, S.V., 2011, Study of water pollution due to Heavy metals in Kukshet lakes of Nerul, Navi Mumbai, India, International Journal of Global Environmental Issues, 11(1), 79-90.

[26] Singare, P.U., Lokhande, R.S., and Jagtap, A.G., 2011, Water pollution by discharge effluents from Gove Industrial Area of Maharashtra, India: Dispersion of heavy metals and their Toxic effects, International Journal of Global Environmental Issues, 11(1), 28-36.

[27] Singare, P.U., Lokhande, R.S., and Pathak, P.P., 2010, Study on Physico-Chemical properties and Heavy Metal Content of the Soil Samples from Thane Creek of Maharashtra, India, Interdisciplinary Environmental Review, 11(1), 38-56.

[28] Singare, P.U., Lokhande, R.S., and Naik, K.U., 2010, A Case Study of Some Lakes Located at and Around Thane City of Maharashtra, India, with Special Reference to Physico-Chemical Properties and Heavy Metal content of Lake Water, Interdisciplinary Environmental Review, 11(1), 90-107.

[29] Klean Environmental Consultants Pvt. Ltd., Mumbai, Survey Report on Mithi River Water Pollution and Recommendations for its Control', Report Submitted To Maharashtra Pollution Control Board (MPCB), Mumbai. Ref.No.0407/Mpcb Mithi River Survey/ 109, July 10, 2004.

[30] Singare, P.U., Lokhande, R.S., and Bhattacharjee, S.S., 2013, Analysis of the Heavy metal Pollutants in Sediment Samples collected from Thane Creek of Maharashtra, India, International Journal of Sustainable Society, 5(3), 296-308.

[31] Al-Shiwafi, N., Rushdi, A. I., and Ba-Issa, A., 2005, Trace Metals in Surface Seawaters and Sediments from Various Habitats of the Red Sea Coast of Yemen., Environmental Geology, 48(4-5), 590-598.

[32] Jung, H., Yun, S., Mayer, B., Kim, S., Park S., and Lee, P., 2005, Transport and Sediment-Water Partitioning Of Trace Metals in Acid Mine Drainage: An Example from the Abandoned Kwangyang Au-Ag Mine Area, South Korea,. Environmental Geology, 48(4-5), 437-449.

[33] Clesceri, L.S., 1998, Standard methods for the examination of water and waste water, in A.E. Greenbergy and A.D. Eaton (Eds.), Collection and Preservation of Samples and Metals. Washington DC: APHA, AWWA, WEF, pp.1-27-1-35, 3-1-3-21. 
[34] Paar, A., 1998, Microwave Sample Preparation System Instruction Handbook. Austria: Anton Paar GmbH, p.128.

[35] Sachdev, S.L., and West, P.W., 1970, Concentration of trace metals by solvent extraction and their determination by atomic absorption spectrophotometer', Environmental Science \& Technology, 4(9),749-751.

[36] Chen, M., and Ma, L.Q., 2001, Comparison of three aqua regia digestion methods for twenty florida soils, Soil Science Society of American Journal, 65(2), 491-499.

[37] Jain, S., and Salman, S., 1995, Heavy metal concentration in highly eutrophic lake sediments and overlying water, Pollution Research, 14(4), 471-476.

[38] Weston, D.P., and Maraya, K.A., 2002, Predicting bioavailability and bioaccumulation with in vitro digestive fluid extraction, Environ Toxicol Chem., 21(5), 962-971.

[39] Kennicutt, M.C., Wade, T.L., Presley, B.J., Requejo, A.G., Brooks, J.M., and Denoux, G.J., 1994, Sediment contaminants in Casco Bay, Maine: inventories, sources and potential for biological impacts, Environ. Sci. Technol., 28(1), $1-15$.

[40] Foy, C.D., Duke, J.A., and Devine, T.E., 1992, Tolerance of soybean germplasm to an acid Tatum subsoil, J. Plant Nutr., 15(5), 527-547.

[41] Delhaize, E., and Ryan, P.R., 1995, Aluminum Toxicity and Tolerance in Plants, Plant Physiol., 107(2), 315-321.

[42] Kochian, L.V., 1995, Cellular Mechanisms of Aluminum Toxicity and Resistance in Plants, Annu. Rev. Plant Physiol. and Plant Mol. Biol., 46, 237-260.

[43] Rout, G.R., Samantaray, S., and Das, P., 2001, Aluminum toxicity in plants: a review', Agronomie, 21(1), 3-21.

[44] Gosh, D., Datta, S., Bhattacharya, S. and Mazumder, S., 2007, Long-term exposure to arsenic affects head kidney and impairs humral immune responses of Clarias batrachus, Aquat. Toxicol., 81(1), 79-89.

[45] Gosh, D., Datta, S., Bhattacharya, S., and Mazumder, S., 2006, Perturbation in the catfish immune responses by arsenic: organ and cell specific effects. Comp. Biochem. Physiol., 143C: $455-463$.

[46] Datta, S., Saha, D.R., Gosh, D., Majumdar, T., Bhattacharya, S., and Mazumder, S., 2007, Sub-lethal concentration of arsenic interferes with the proliferation of hepatocytes and induces in vivo apoptosis in Clarias batrachus L., Comp. Biochem. Physiol. Part C, 145(3), 339-349.

[47] Sethi, P.K., Khandelwal, D.J., and Sethi, N., 2006, Cadmium exposure: Health hazards of silver cottage industry in developing countries, J. Med. Toxicol., 2(1), 14-15.

[48] Bernard, A., 2008, Cadmium \& its adverse effects on human health, Indian J. Med. Res., 128(4), 557-564.

[49] Johri, N., Jacquillet, G., and Unwin, R., 2010, Heavy metal poisoning: the effects of cadmium on the kidney, BioMetals, 23(5), pp. 783-792.

[50] Godt, J., Scheidig, F., Grosse-Siestrup, C., Esche, V., Brandenburg, P., Reich, A, et al., 2006, The toxicity of cadmium and resulting hazards for human health, J. Occup. Med. Toxicol., 1, 22.
[51] Geller, R., 2001, "Chromium." In:Clinical Environmental Health and Toxic Exposures. Sullivan, JB, Jr. and Krieger, GR, editors. 2nd Ed. Lippincott Williams \& Wilkins, Philadelphia, PA.

[52] Lewis, R., 2004, "Occupational Exposures: Metals. In: Current Occupational \& Environmental Medicine. LaDou, J. editor. $3^{\text {rd }}$ Ed." Lange Medical Books/McGraw-Hill Companies, Inc.: pp. 439-441.

[53] Rom, W. N., 2007, Environmental and Occupational Medicine. 4th Ed. 2007 by Lippincott Williams \& Wilkins.

[54] Velma, V., Vutukuru, S.S. and Tchounwou, P.B., 2009, Ecotoxicology of Hexavalent Chromium in Freshwater Fish: A Critical Review, Rev. Environ. Health., 24(2): 129-145.

[55] Steinhagen, D., Helmus, T., Maurer, S., and Michael, R.D., Leibold, W., Scharsack, J.P., et al., 2004, Effect of hexavalent carcinogenic chromium on carp Cyprinus carpio immune cells. Dis Aquat Organ., 62(1-2):155-61.

[56] Cho, U., Park, J.O., 2000, Mercury induced oxidative stress in tomato seedlings, Plant Science, 156(1), 1-9.

[57] Zhou, Z.S., Huang, S.Q., Guo, K., Mehta, S.K., Zhang, P.C., and Yang, Z.M., 2007, Metabolic adaptations to mercuryinduced oxidative stress in roots of Medicago sativa L, Journal of Inorganic Biochemistry, 101(1), 1-9.

[58] Favretto, L., Campisi, B., Reisenhofer, E., and Adami, G., 1997, Sewage pollution, Anal. Chim. Acta, 344(3), 251-259.

[59] Tanaka, K., 1977, Photochemical alkylation of inorganic mercury in sewage treatment plant waste waters, Kanagawa-ken Kogai Senta Nenpo 10(1), 198-201.

[60] Goldstone, M. E., Atkinson, C., Kirk, P. W.W., and Lester, J. N., 1990, The behaviour of heavy metals during waste water treatment, Science of the Total Environment, 95(1), 271-294.

[61] Horvat, M., Liang, L., Azemard, S., Mandic, V., Villeneuve, J.P, and Coquery, M., 1997, Certification of total mrecury and methylmercury concentrations in mussel homogenate (Mytilus edulis) reference material, IAEA-142 (Lecture). Fresenius' J. Anal. Chem., 1997, 358(3), 411-418.

[62] Bodaly, R. A., Rudd, W. M., and Flett, R. J., 1998, Effect of urban sewage treatment on total and methyl mercury concentrations in effluents, Biogeochemistry, 40(2-3), 279-291.

[63] Nriagu, J.O., and Pacyna, J.M., 1988, Quantitative assessment of world wide contamination of air, water and soils by trace metals, Nature, 333(6169), 134-139.

[64] Baralkiewicz, D., Siepak, J., 1999, Chromium, nickel and cobalt in environmental samples and existing legal norms, Polish J. Environ. Studies, 8 (4), 201.

[65] Kashulin, N.A., Ratkin, N.E., Dauvalter, V.A., and Lukin, A.A., 2001, Impact of airborne pollution on the drainage area of subarctic lakes and fish, Chemosphere, 42 (1), 51.

[66] Haber, L.T., Erdreicht, L., Diamond, G.L., Maier, A.M., Ratney, R., Zhao, Q., and Dourson, M.1., 2000, Hazard identification and dose response of inhaled nickel-soluble salts, Regul. Toxicol. Pharmacol. 31(2), 210-230.

[67] Kasprzak, K.S., Sunderman, F.W., and Salnikow, K., 2003, Nickel carcinogenesis, Mutat. Res., 533 (1-2), 67. 
[68] IRIS. Nickel, soluble salts. 1996. web site: http://www.epa.gov/iris/subst/0271.htm (accessed 06.07.2005).

[69] Birdsall, C.W., Grue, C.E., and Anderson, A., 1986, Lead concentrations in bullfrog Rana catesbeiana and green frog $R$. clamitans tadpoles inhabiting highway drainages, Environ. Pollut., 40(3):233-247.

[70] Fantin, A.M.B., Franchini, A., Ottaviani, E., and Benedetti, L., 1985, Effect of pollution on some freshwater species. II. Bioaccumulation and toxic effects of experimental lead pollution on the ganglia in Viviparus ater (Mollusca, Gastropoda), Basic Appl. Histochem., 29(4), 377-387.

[71] Griffin, A.E., 1960, Significance and removal of manganese in water supplies, J. Am. Water Works Assoc., 52(10), 1326-1334.

[72] Bean, E.L., 1974, Potable water-quality goals, J. Am. Water Works Assoc., 66(4), 221-230.

[73] Wolfe, R.S., 1960, Microbial concentration of iron and manganese in water with low concentrations of these elements, J. Am. Water Works Assoc., 52(10), 1335-1337. 